慶應義塾大学学術情報リポジトリ

Keio Associated Repository of Academic resouces

\begin{tabular}{|c|l|}
\hline Title & $\begin{array}{l}\text { Stereospecificity of the hydride transfer reaction catalyzed by isopropylmalate dehydrogenase of } \\
\text { thermophilic bacteria thermus thermophilus }\end{array}$ \\
\hline Sub Title & \\
\hline Author & $\begin{array}{l}\text { 山田, 徹(Yamada, Toru) } \\
\text { 柿沼, 勝己(Kakinuma, Katsumi) } \\
\text { 遠藤, 豊成(Endo, Toyoshige) } \\
\text { 大島, 泰郎(Oshima, Tairo) }\end{array}$ \\
\hline Publisher & 共立薬科大学 \\
\hline Publication year & 1987 \\
\hline Jtitle & $\begin{array}{l}\text { 共立薬科大学研究年報 (The annual report of the Kyoritsu College of } \\
\text { Pharmacy). No.32 (1987.),p.100- 100 }\end{array}$ \\
\hline JaLC DOI & \\
\hline Abstract & \\
\hline Notes & 抄録 \\
\hline Genre & Technical Report \\
\hline URL & $\begin{array}{l}\text { https://koara.lib.keio.ac.jp/xoonips/modules/xoonips/detail.php?koara_id=AN00062898-0000003 } \\
\text { 2-0100 }\end{array}$ \\
\hline
\end{tabular}

慶應義塾大学学術情報リポジトリ(KOARA)に掲載されているコンテンツの著作権は、それぞれの著作者、学会または出版社/発行者に帰属し、その権利は著作権法によって 保護されています。引用にあたっては、著作権法を遵守してご利用ください。

The copyrights of content available on the KeiO Associated Repository of Academic resources (KOARA) belong to the respective authors, academic societies, or publishers/issuers, and these rights are protected by the Japanese Copyright Act. When quoting the content, please follow the Japanese copyright act. 


\title{
Stereospecificity of the Hydride Transfer Reaction Catalyzed by \\ Isopropylmalate Dehydrogenase of Thermophilic Bacteria Thermus thermophilus
}

\author{
Tohru Yamada*, Katsumi Kakinuma*, Toyoshige Endō and Tairo Oshima* \\ 山田 徹*, 杮沼勝巳*, 遠藤豊成, 大島泰郎*
}

In the leucine biosynthesis, threo- $\mathrm{D}_{\mathrm{s}}$-3-isopropylmalate dehydrogenase (IPMDH) is responsible for the conversion of isopropylmalate (IPM) to 2-oxoisocaproic acid. NMR studies on the NAD-dependent reaction catalyzed by IPMDH from $T$. thermophilus HB 8 revealed that pro $R$ specific (A specific) hydride transfer from the substrate to the nicotinamide ring is involved during the said oxido-reduction.

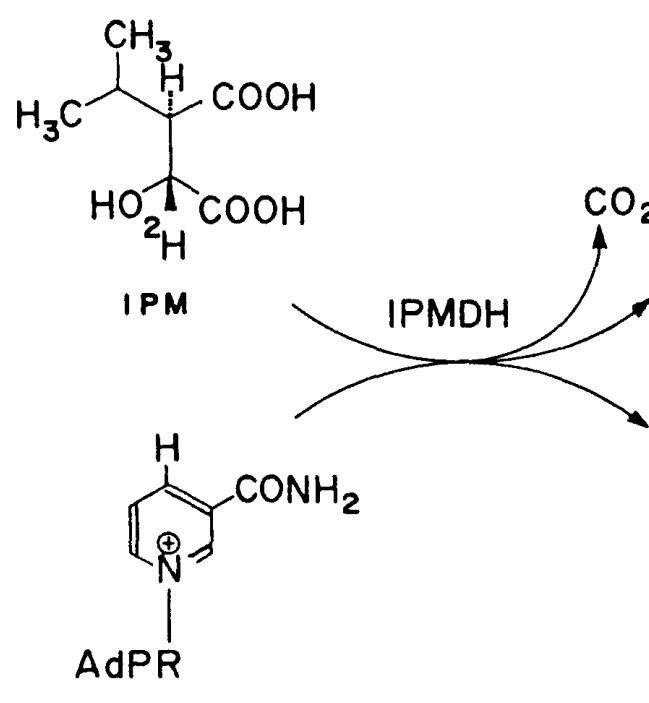

NAD<smiles>CC(C)CC(=O)C(=O)O</smiles>

2-oxoisocaprolc acld<smiles>[14CH3]n1cc[14cH]c1</smiles>

NADH

* Department of Life Science, Tokyo Institute of Technology. 